CHAPTER 7

\title{
OCCULT AND PULP VISIONS OF GREECE AND ROME IN HEAVY METAL
}

Jared Secord

Introduction

Just as its name suggests, the Flemish black metal band Ancient Rites displays a major interest in the premodern world, including Greco-Roman antiquity. Greece and Rome are represented especially on the band's 2006 album Rubicon, which features songs about Julius Caesar, the Battle of Thermopylae, and Arminius, who inflicted on Rome the great defeat at the Battle of the Teutoburg Forest in $9 \mathrm{CE}$. But the band's fascination with the premodern world extends beyond Greece and Rome, revealing an approach to antiquity that differs in many ways from the academic study of the Classics and Greek and Roman history. This approach is prominently on display in the band's 2001 album Dim Carcosa, and the substantial liner notes that accompany it. Written by Gunther Theys, the band's lyricist and vocalist, the notes explain the background for the album's songs, with emphasis on the books that inspired them. There are Greek and Roman books among this list: Homer's Iliad and Caesar's Gallic War. ${ }^{1}$ Medieval books are likewise present, including the Song of Roland, and, more obscurely, a twelfth-century history that describes a Viking attack on the British monastery of Lindisfarne in $793 \mathrm{CE}{ }^{2}$

Theys, however, also describes his interests in even more arcane subjects. These revolve around the ancient and mysterious city of Carcosa that appears in the album's title. This city is entirely fictional. It first appeared in a story by the American writer Ambrose Bierce (1842-1914), and then took on a long afterlife in horror and fantasy literature, even making a prominent recent appearance in the first season of HBO's True Detective. $^{3}$ As Theys reveals, he was first exposed to Carcosa by a reference to it in a popular occult book, Anton Szandor LaVey's Satanic Bible. ${ }^{4}$ This reference inspired Theys to research whether Carcosa might be a real place, leading him to read deeply in what he describes as "mystical esoteric" subjects, including the Knights Templar freemasonry, and something called "Tantric Alchemy." Theys' search led him to conclude that Carcosa was unlikely to be real, but he remained intrigued by the possibility that it may have been connected to the French town of Carcassone, whose name under the Roman Empire was Carcaso. ${ }^{5}$ Clearly, Theys has a major interest in the ancient and medieval history of Europe. This has been fueled by reading books on eclectic topics, and a desire to explore esoteric questions about the world's premodern past.

The esoteric interests of Ancient Rites are not uncommon in heavy metal (henceforth simply "metal") and my focus here is on how esotericism informs the reception of Greek and Roman antiquity within the genre. The scope of my examination is limited to what I 
shall call "esoteric metal," a label that includes bands from a few different subgenres, especially black, death, and symphonic metal. ${ }^{6} \mathrm{I}$ use this label to describe not the sound or musical style of the bands, but rather the themes that they explore in their albums and lyrics. As with Gunther Theys and Ancient Rites, esoteric metal bands tend to be interested in the more arcane and mysterious aspects of the ancient world, which are not typically connected to Greco-Roman antiquity. The bands that interest me approach arcane material in a particularly bookish manner, a common phenomenon within the extreme metal scene. ${ }^{7}$ Bookishness is a key part of the production and reception of esoteric metal, which allows both musicians and fans to discover and explore things that intrigue them about the world's ancient past. Esoteric metal is defined by the act of reading, and the process of trying to find new and unfamiliar arcane subject matter worthy of exploration for musicians and fans. ${ }^{8}$ Like Gunther Theys, lyricists in esoteric bands read broadly and eclectically, exploring many topics revolving around the world's premodern past. This wide reading reflects the bands' deep fascination with the world's ancient past, and not just Greece and Rome. Esoteric bands often take an indiscriminate approach to the history of the ancient world, favoring books and ideas that are not taken seriously by professional Classicists and ancient historians, and exploring mysterious subjects like the entirely fictional ancient city of Carcosa. This approach to antiquity is a fundamental part of esoteric metal, and of its engagement with Greece and Rome alongside other aspects of the world's ancient past.

Two key sources inform the reception of Greece and Rome in esoteric metal. The first of these is the occult tradition, which is the subject of the chapter's first section. Occultism is heavily concerned with hidden or rejected knowledge from the ancient world, such as astrology and magic. ${ }^{9}$ Its influence encourages esoteric bands to turn away from Greek and Latin works that have been accepted as Classics, a category that has often been linked with the ideas of harmony, balance, and rationality. ${ }^{10}$ It has likewise prompted esoteric bands to link Greece and Rome with other ancient civilizations, and to seek out commonalities between their religious traditions, in keeping with occult views on this point. The chapter's second part then considers the influence of the other key source for esoteric metal: pulp fiction, especially as represented in the horror and fantasy stories published in the magazine Weird Tales in the first half of the twentieth century. ${ }^{11}$ The influence of these stories helps to explain why esoteric bands tend to focus more of their attention on ancient civilizations besides Greece and Rome, deeming them too civilized to be appropriate sources for terror and alienation. Stories in Weird Tales are also responsible for a popular idea within esoteric metal: entirely fictional ancient books that contain terrifying information about the world's distant past. Both occultism and pulp fiction therefore help to fuel the interests of esoteric metal bands in the ancient world, while steering them mostly away from Greece and Rome.

The influence of Weird Tales stories and the occult tradition means that esoteric metal tends to present the world's premodern history in ways that now seem old-fashioned, and sometimes even problematic, from the perspective of professional Classicists and ancient historians. In one sense, this is a straightforward consequence of esoteric metal bands drawing from nineteenth- and early-twentieth-century views on history for their presentations of the ancient world. Greece and Rome consequently still appear largely as familiar, safe places, and insufficiently mysterious or exotic for sustained exploration. ${ }^{12}$ There are definite traces here of Eurocentrism and Orientalism of the type that feature prominently in Weird Tales stories and the occult tradition. ${ }^{13}$ Sometimes there are even definite signs of nationalism, such as in the case of Gunther Theys, who has become a controversial figure in Belgium because of his emphasis on Flemish history and identity. ${ }^{14}$ But the esoteric bands that interest me in the remainder of this chapter are emphatically not fascist in their views, much less members of the marginal National Socialist Black Metal scene, which is widely condemned by other metal fans and musicians. ${ }^{15}$ These bands have nothing explicit to say about contemporary politics or race in their music, a phenomenon that fits in with a generally apolitical tendency in many subgenres of metal around the turn of the twenty-first century. ${ }^{16}$ Eurocentric and Orientalist ideas nonetheless do still abound in esoteric metal, fueled in large part by the older attitudes on history found in occultism and pulp fiction, which help to make ancient civilizations besides Greece and Rome seem more interesting.

What emerges in esoteric metal's view of premodern history is a complicated reception of Greece and Rome that depends much on their connotations of familiar antiquity. Both civilizations are valuable because they can easily evoke feelings of the ancient world, while sometimes providing glimpses of other, less familiar and civilized aspects of antiquity, as in their encounters with peoples to the north, east, and south of the Mediterranean world. Greece and Rome are defamiliarized somewhat by these associations, and by the interests that esoteric metal bands sometimes display in forms of rejected knowledge from the two civilizations, such as magic. These interests mostly parallel developments within the academic study of the Classics and Ancient History, which have increasingly treated Greece and Rome as less familiar places in the last four decades. ${ }^{17}$ But a Eurocentric Classical perspective still generally prevails within esoteric metal. This Eurocentrism is especially prominent in the common assumption that knowledge of the world's ancient past is filtered through Europe and its reception by Classically trained scholars. Esoteric metal consequently has a paradoxical attitude toward the world's ancient past. It regards Greece and Rome as basically uninteresting places for exploration, mostly avoiding songs and albums on topics that are popular within Mediterranean metal. At the same time, though, esoteric metal bands tend to present Greco-Roman antiquity in a larger context, associating it with other, more arcane and mysterious aspects of the ancient world.

\section{The great beast and a perennial philosophy: The ancient world} in esoteric metal via the occult

Metal's fascination with the occult is obvious, and it has been part of the genre from its earliest beginnings, as is clear from Black Sabbath's engagement with magical and arcane subject matter on their debut album from $1970 .{ }^{18}$ Much of this interest in the occult, however, has taken generic forms, inspired and sanctioned by the presence of demons and sorcerers in the cover artwork and lyrics of bands like Black Sabbath, and by the 
popularity of Aleister Crowley (1875-1947), the massively influential occult figure who titled himself "The Great Beast." ${ }^{\prime 19}$ Little real engagement with the ancient world has resulted from this generic type of occultism, apart from vague appeals to antiquity of the sort parodied in Spinal Tap's "Stonehenge" ("In ancient times ... / Hundreds of years before the dawn of history / Lived a strange race of people ... the Druids").$^{20}$ But some metals bands, beginning in the 1980s, have engaged more directly and creatively with the occult tradition, and with the ancient sources of wisdom that continue to inspire it.

This section focuses on two significant examples of esoteric metal's engagement with the occult tradition. The first is a Swiss band, Celtic Frost, which was influential in the early development of more extreme forms of metal in the $1980 \mathrm{~s}$, anticipating and inspiring the experimentation of many subsequent black and death metal bands. ${ }^{21}$ Celtic Frost's use of Greek helps to reveal how this language is often valued in metal for its significance within occult traditions, and the evocative associations that it consequently has. Outside this occult context, Greco-Roman antiquity has little presence in Celtic Frost's work, despite the band's major interest in the ancient world. The second example treated is Therion, a Swedish band influential for its pioneering blend of metal with Classical instruments and choral vocals. ${ }^{22}$ Therion stands out even within esoteric metal for the closeness of its connections to the occult tradition. Like Celtic Frost, Therion is interested in the ancient and occult associations of Greece and Rome, but the band has a much broader interest in the world's premodern past. Greco-Roman antiquity has a place in Therion's music, but always alongside the ancient civilizations of Egypt and the Near East, and even Atlantis and Lemuria, in keeping with the unorthodox views on the world's history championed in the occult tradition. ${ }^{23}$ Therion presents all of these ancient civilizations as part of the philosophia perennis ("perennial philosophy") identified by occult scholars who wished to establish a basic unity between the world's different religious traditions. ${ }^{24}$ Celtic Frost and Therion both defamiliarize Greece and Rome somewhat by approaching them via the occult tradition, while still regarding both civilizations as insufficiently exotic for much exploration.

To take Celtic Frost first: the band's approach to the world's premodern past reveals a deep fascination with arcane and occult subject matter at the expense of Greece and Rome. Such fascination derives in large part from the attitude that one of the band's founding members, Tom Gabriel Fischer, has concerning formal education. "I love learning things," writes Fischer, "but I hate being told what to learn." ${ }^{25}$ Fischer found an outlet for his desire to learn outside of school, reading books about "ancient and modern history, occultism, religion, [and] the supernatural," all topics that also interested Celtic Frost's bass player, Martin Eric Ain ${ }^{26}$ Ain was raised in a strict Catholic family, but even in his teens he would make trips to a library in Zurich, which was the only place where he could access books by Crowley and other occult authors. ${ }^{27}$ Greco-Roman antiquity evidently was insufficiently arcane to be worthy of exploration on Celtic Frost's albums, which instead are dotted with references to other ancient civilizations; Egypt, Carthage, and Babylon all make multiple appearances. ${ }^{28}$ These civilizations are accompanied by the Celts represented in the band's own name, reflecting Fischer's interest in the ancient peoples of his native Switzerland. ${ }^{29}$ Greece and Rome are conspicuously absent amidst such company.
The wide reading of Fischer and Ain nonetheless led them to explore some of the more obscure corners of Greco-Roman antiquity. The best sign of such exploration comes from the odd title of Celtic Frost's 1992 album, Parched with Thirst Am I and Dying. This title is a common phrase used in the Orphic gold tablets, which were interred in graves in many regions of the Greek world from as early as the fifth century $B C E .{ }^{30}$ The tablets have received increasing attention from scholars, and have become much more accessible to non-specialists, in keeping with the ongoing movement within Classics to defamiliarize the ancient world. ${ }^{31}$ But Celtic Frost's album was released before this recent boom of interest. The band evidently accessed the tablets through a brief discussion published in 1977 by Joseph Breslin, which offers a translation of three tablets, two of which include the phrase "Parched with thirst am I, and dying." ${ }^{32}$ In his memoir, Fischer says that the quotation comes from "a fourth-century Greek-Roman poem found among the ashes of a dead man."33 This identification is not entirely accurate: the tablet in question seems to be one found at Hipponion in southern Italy, hence Fischer's use of the odd "Greek-Roman" label. The tablet does date to $\mathrm{ca} .400 \mathrm{BCE}$, but it was discovered on top of a woman's skeleton, not "among the ashes of a dead man," as Fischer claims. ${ }^{34}$ Fischer's identification nonetheless makes clear the appeal he saw in the phrase, which fits in well with the band's morbid and dark interests. The obscurity of the tablet, combined with the circumstances of its discovery, made it more appealing to the band than less mysterious and sinister aspects of Greek and Roman antiquity.

Greco-Roman antiquity is present in Celtic Frost's albums via the use of Greek phrases, but this depends on the more occult and evocative associations of the language. These associations are especially clear from the title of the band's 1985 album, To Mega Therion, which is transliterated from the Greek for Crowley's preferred title of "The Great Beast" (he frequently claimed that he was the beast from Revelations 13). The Greek phrase here is familiar to those with occult interests, for whom the phrase evokes Crowley (and possibly the New Testament) rather than anything to do with Greco-Roman antiquity. Celtic Frost's fondness for using Greek album titles with occult associations continues in Fischer's new band Triptykon, whose name is transliterated directly from the Greek, in preference to the Latinized spelling of the English "Triptych." The band's 2010 album is called Eparistera Daimones (literally: "Left-side Demons"), a phrase that is taken from a ritual included in Crowley's 1913 Book of Lies. ${ }^{35}$ This phrase clearly has intrigued fans of Triptykon, who have discussed its meaning and occult significance on the band's online discussion forum. ${ }^{36}$ This forum also contains much speculation about the meaning of the Greek phrase used for the band's 2014 album title, Melana Chasmata. There is no occult significance to this title, which simply means "Black Chasms." Fischer writes on the forum that it was meant to reflect "the circumstances around the creation of the album as well as [its] atmosphere."37 But fans of the band nonetheless have sought to discover deeper meanings in the title, based on the implicit assumption that Greek words and phrases used by the band cannot be translated so simply into English. ${ }^{38}$ Fans of Celtic Frost and Triptykon evidently enjoy the process of trying to find significance in the Greek titles used by the bands. Greek is unfamiliar to most of their fans, but is simultaneously resonant, due to its continued use in a variety of different contexts, 
scientific, occult, and otherwise. As an ancient language, Greek clearly seems to possess power for some fans of esoteric metal, who treat each use of it almost as a magical incantation. ${ }^{39}$ Though Celtic Frost engage sparingly with Greco-Roman antiquity, Greek is still valuable to the band because of its evocative unfamiliarity and esoteric associations.

Celtic Frost's influential example helped to inspire Therion, a band that has offered since its foundation in the late 1980s a brand of occult-tinged metal that continues to draw on the more esoteric associations of Greco-Roman antiquity. Therion's occult interests are clear first from the band's name, which was itself a shortened form of an earlier version: Megatherion. ${ }^{40}$ The name looks back to Celtic Frost's To Mega Therion, and from it to Crowley, demonstrating again how metal uses Greek to evoke the occult tradition, rather than Greek antiquity. ${ }^{41}$ But Therion's occult connections go far beyond those of Celtic Frost. Since 1991, the band's founder, Cristofer Johnsson, has been a member of Dragon Rouge ("Red Dragon"), a Swedish magical order that values individualism and antinomianism, and is similar in some respects to the Church of Satan. ${ }^{42}$ The founder of Dragon Rouge, Thomas Karlsson (b. 1971) was, in turn, the main lyricist on Therion's studio albums released between 1996 and 2010.43 As Kennet Granholm notes, Therion has not been a "mouthpiece" for Dragon Rouge, but the order still has a notable presence in the band's music." Even before Karlsson began contributing lytics, Therion's albums showed signs of the band's connections to Dragon Rouge, notably through the use of transliterated Greek. The band's 1993 album, Symphony Masses: Ho Drakon Ho Megas ("The Great Dragon"), includes as its subtitle a phrase often used in rituals performed by Dragon Rouge..$^{45}$ As was the case for Crowley nearly a century ago, Greek still has a place in the rituals of a modern occult order. This ritualistic, occult usage of Greek has been passed on to Therion.

Despite the band's use of Greek in some song and album titles, Greco-Roman antiquity has a small place in the albums of Therion, which offer wide-ranging engagement with the world's ancient wisdom in keeping with the perennial philosophy championed by Dragon Rouge and its founder. The order's perennialist outlook is supported by its academic and eclectic approach to the study of ancient religions. Its founder has a Ph.D. in the History of Religions from Stockholm University, and some of its members have learned Arabic, Sanskrit, and other languages to further their studies. ${ }^{46}$ All of this training is put to use in the academic-style presentations that take place at retreats sponsored by the order, which cover a range of topics, including the depiction of dragons in Arabic literature and mythology. ${ }^{47}$ The order's rituals likewise contain a heavy dose of eclecticism. To cite one significant example, its Dragon Ceremony includes a list of "dragon-like creatures drawn from various mythologies," climaxing with the repeated chanting of the Greek phrase "Ho Drakon Ho Megas." 48

Therion's coverage of the premodern world is similarly eclectic. The band's doublealbum Lemuria/Sirius B, released in 2004, features songs that engage with Norse, Egyptian, Indian, and Greek mythology, not to mention the lost civilization of Lemuria named in the title. ${ }^{49}$ 'The eclecticism of the order's rituals and presentations also appears in both the lyrics and the music of 'Therion's songs. Even in Therion's earliest days as a death metal band, its music included keyboards and choral vocals, both elements that were foreign to the genre at the time. ${ }^{50}$ As Therion made the transition to a symphonic metal band in the mid-1990s, incorporating Classical instruments and yet more choral vocals into its sound, it continued to explore non-Western styles of music, particularly in songs with lyrics relating to Egyptian mythology. ${ }^{51}$

A telling example of the band's eclecticism comes in the song "Adulruna Rediviva," from the 2007 album Gothic Kabbalah. This is a concept album based on the subject of Karlsson's Ph.D. dissertation, the Swedish scholar Johannes Bureus (1568-1652), who found mystical significance in the runic alphabet of early Germanic languages. ${ }^{52}$ Bureus presented his theories in a work called Adulruna Rediviva ("The Noble Rune Reborn"), hence the title of Therion's song. ${ }^{53}$ This song explores multiple sources of ancient wisdom from different traditions, including in its lyrics a call to a group of prophetesses and goddesses: the Sibyls, the Gnostic figure Sophia (who is called the "female Christ"), Aphrodite, and Venus. There is also an appeal to a diverse group of real and imagined philosophers: "Hermes Trismegistos, Orpheus, Zarathustra, Pythagoras, and Plato." ${ }^{24}$ The list of philosophers is organized according to early-modern views on their relative chronology, and implies a continuity to their teachings, thus combining Egyptian, Iranian, and Greek traditions into one. ${ }^{55}$ The literature linked to Hermes Trismegistus has long since been identified as late pseudepigrapha, but his name still stands in Therion's song at the head of this succession of philosophers. ${ }^{56}$ Fittingly, all of this takes place in a song that combines male and female vocalists, a full choir, and a mix of metal and symphonic instruments, all displaying the many different musical influences acting on the band ${ }^{57}$ The title of the song is in Latin, and it contains references to Greek and Roman philosophy and mythology, but it nonetheless owes most to the occult tradition, drawing on the works of Bureus and others who sought to unite the world's ancient religious traditions into one.

Occult perspectives on the world's premodern past have thus had a considerable impact on the reception of Greco-Roman antiquity within esoteric metal. Celtic Frost and Therion provide two particularly significant examples of occultism's influence, thanks to their popularity and influence within the genre. But there also are many bands with similar interests, including others with links to Dragon Rouge.$^{58}$ For all these bands, occultism offers a more compelling perspective on the premodern past than one that emphasizes the Classical associations of Greece and Rome. Like Therion and Celtic Frost, these bands might well have a major interest in these countries exclusively, but most of this interest is likely to be directed at arcane and mysterious material such as the Orphic gold tablets than what we might think of as the mainstream Classical world. Greco-Roman antiquity's connections to the occult tradition are what matter most to esoteric metal bands.

\section{Exotic pasts and forgotten books: The ancient world in esoteric} metal via Robert E. Howard and H. P. Lovecraft

Alongside metal's fascination with the occult, many bands also have a major interest in pulp literature from the first half of the twentieth century, particularly the stories of 
H. P. Lovecraft (1890-1937) and Robert E. Howard (1906-1936), many of which were originally published in Weird Tales. ${ }^{59}$ Lovecraft has enjoyed a significant following among metal bands since the 1980s, when his characters, especially the ancient octopus-headed entity called Cthulhu, began to appear with some frequency in metal songs, such as Metallicas "The Call of Ktulu." 60 Howard's stories, too, have had an increasing presence in metal since the early 1980s, when his most famous creation was played by Arnold Schwarzenegger in the film Conan the Barbarian. ${ }^{61}$ Lovecraft's appeal to metal bands owes much to the genre's longstanding interest in horror and madness, just as Howard's popularity in metal depends heavily on the violence and darkness of his hyper-masculine stories. ${ }^{62}$

But the interest of esoteric metal bands in Lovecraft and Howard is often linked to a larger fascination with the world's premodern past. One band with such interests is Britain's Bal-Sagoth, who engage at length with the premodern world in six albums released between 1995 and $2006 .{ }^{63} \mathrm{Bal}-$ Sagoth may not enjoy the popularity and influence of other metal bands that have been inspired by the stories of Lovecraft and Howard, including the American band Nile, and the Danish band Mercyful Fate, ${ }^{64}$ but their albums offer an unmatched level of engagement with the works of Lovecraft and Howard that can illustrate, in concentrated form, the larger influence that these authors have had on esoteric metal's reception of the ancient world. ${ }^{65}$ This engagement with Lovecraft and Howard is owed largely to Bal-Sagoth's founder and lyricist, Bryon A. Roberts, who is also an aspiring author of dark fantasy and horror stories.$^{66}$ Roberts was responsible for the naming of the band, which comes from a story by Howard called "The Gods of Bal-Sagoth," originally published in Weird Tales in $1931 .{ }^{67}$ Dark fantasy and horror stories are an entirely fitting source of inspiration for the unusual music of Bal-Sagoth, which Roberts describes as "symphonic baroque fantasy black metal."68 In Bal-Sagoth's albums, the typical screamed vocals and high-treble guitars of black metal are joined with frequent use of spoken dialogue, and supplemented further with symphonic effects produced by synthesizers, giving the band a distinctive sound that takes much inspiration from film music. ${ }^{69}$ The band is also notorious for having song titles of great length, written in the overwrought and archaizing style familiar from the works of Howard and Lovecraft. ${ }^{70}$

The eclecticism of Bal-Sagoth's music is matched by its wide-ranging engagement with the premodern world. The stories of Howard and Lovecraft serve as a major source of inspiration for the band's treatment of the world's distant and forgotten past, which mostly bypasses Greco-Roman antiquity. This treatment takes the form of an invented history filled with a diverse mix of peoples and places, complete with an imaginary work of ancient literature. Roberts has even put together a large online glossary of his invented world, identifying the hundreds of peoples and places that appear in it. ${ }^{71}$ Bal-Sagoth does draw from Greco-Roman antiquity as a source of inspiration for its invented history, but the band has only limited interest in Greece and Rome. ${ }^{72}$ As was the case for Lovecraft and Howard, Greco-Roman antiquity is simply too civilized to have a major place in BalSagoth's exploration of premodernity. The band is instead more interested in civilizations that evoke a lost ancient world, following the lead of Howard and Lovecraft in exploring the imaginative and horrific potential of humanity's forgotten history.
Bal-Sagoth's exploration of the world's distant past via an invented history of humanity follows the lead of Howard, whose own invented "Hyborian World" was meant to convey to readers a feeling of familiar but mysterious antiquity. ${ }^{73}$ The invented worlds of BalSagoth and Howard do include many Greek and Latin words and names, but they draw on many other sources besides Greco-Roman antiquity, mixing together a wide range of traditions. The mix of names that form Bal-Sagoth's invented "antediluvian world" is clear even from a cursory examination of the band's album and song titles, which include references to Atlantis, Hyperborea, Lemuria, $\mathrm{Mu}$, and Ultima Thule. ${ }^{74}$ Atlantis derives ultimately from Plato, and Hyperborea and Ultima Thule were used by Greek and Roman authors to refer to far-off places in the mysterious north. ${ }^{75}$ The lost continents of Lemuria and $\mathrm{Mu}$, however, were inventions of the nineteenth century that have gained popular familiarity as signifiers of the world's distant past. ${ }^{76}$ All of these places are also part of Howard's invented world, which used names that were meant to be familiar to readers. ${ }^{77}$ Roberts follows Howard's example, and places the lost continents, along with Hyperborea and Ultima Thule, in their "correct" places on the map of his world, which fittingly includes a "Middle Sea" where one might expect to find the Mediterranean. ${ }^{78}$ Howard and Bal-Sagoth both, therefore, offer a familiar map, filled with an eclectic range of names that have ancient associations. Within this mix, Greece and Rome are slightly defamiliarized by being linked with lost continents, but they still serve as the most familiar parts of the maps.

More signs of the eclectic nature of Bal-Sagoth's invented antediluvian world derive from the anachronistic use of Latin. In one of the band's several songs about Hyperborea, the warriors of this land inexplicably hail their king with a Latin phrase "Imperius Rex," which is evidently intended to mean "Imperial King."79 Latin has a prominent place in another of the band's songs, where it is used alongside a bewildering range of other words and concepts that are meant to convey a feeling of antiquity. The song concerns a force of "Dragon Lords" in an allegorical version of ancient Britain, which is called by its alternative Latin name of "Albion." ${ }^{80}$ Remarkably, the song includes a quotation from Beowulf in the original Old English, a reference to a system of writing called "Dragon Runes," and the implication that the Dragon Lords of Albion followed the convention of the Roman army in naming their units, one of which is called the "IX Legio Draconis" ("Ninth Legion of the Dragon"). ${ }^{81}$ Latin does have a prominent place in the song, but is linked with other languages, both real and invented, that also have ancient connotations. Bal-Sagoth's invented antediluvian world, much like Howard's Hyborian world, exploits Greek or Roman names in its attempt to create an atmosphere of familiar antiquity, joining these names with an eclectic mix of other ancient signifiers that have nothing to do with Greece or Rome.

Bal-Sagoth's invented world is accompanied by an imaginary, evil book of great antiquity that surely qualifies as an example of rejected knowledge but is nonetheless linked to Greco-Roman antiquity through its title and the history of its transmission. This book, The Chthonic Chronicles, is the subject of Bal-Sagoth's 2006 album, which was inspired by the example of Lovecraft and a group of other writers, including Howard, who all contributed to the creation of an entire body of imaginary ancient literature that 
they would cite in their stories. ${ }^{82}$ By far the most famous of these books is Lovecraft's own Necronomicon, which shares with Bal-Sagoth's Chthonic Chronicles a complicated relationship with Greco-Roman antiquity, spelled out at length by both Lovecraft and Roberts in transmission histories of their fictitious books. ${ }^{83}$ Tellingly, neither book was originally written in Greek, despite the Greek roots used in their titles. The Necronomicon, as Lovecraft explained in his essay "The History of the Necronomicon," was originally the work of a "mad Arab" of the eighth century named Abdul Alhazred, but it was translated into Greek in the tenth century. ${ }^{84}$ Lovecraft evidently recognized that Necronomicon, with its clear connotations of death to English-speakers, would resonate much more strongly than the book's original Arabic title of Al Azif that he had assigned to it. ${ }^{85} \mathrm{Bal}$ Sagoth's book, meanwhile, was written in "Old High Atlantean," and addressed to a divinity named Khthon, who was worshipped in several different forms by the peoples of Lemuria, Atlantis, Ultima Thule, and Hyperborea ${ }^{86}$ There is nothing Greek about the divinity Khthon, though his name is a transliteration of the Greek word for "earth," evidently spelled with an initial $\mathrm{K}$ to make the name seem more exotic. ${ }^{87}$ "Chthonic" may not be used much in English, but Roberts evidently liked both its strong associations to the Underworld, and its similarity to Lovecraft's Cthulhu; Roberts even explains on his website that this similarity to "Cthulhu," a tri-syllabic word, is why he pronounces "chthonic" incorrectly ("katonic") on the album. ${ }^{88}$ The album's title still has some remote associations with Greek antiquity, but the similarity of "Chthonic" to "Cthulhu" may ultimately resonate most for some listeners of the band ${ }^{89}$ Roberts follows Lovecraft in ensuring that there is separation between his invented book and Greece, despite the prominent use of a Greek root in its title.

Additional signs of this separation from the Classical world come from the handling of the purported Latin translations of the Necronomicon and the Chthonic Chronicles, which are identified as the only extant forms of the two fictitious books by both Lovecraft and Bal-Sagoth. The Latin translation of the Necronomicon, Lovecraft explained, was made directly from the Greek in the thirteenth century, and is the version most often mentioned in his stories. ${ }^{90}$ Though the Necronomicon is not a Greek or Roman book, Lovecraft took for granted that its contents would be transmitted to the world thanks to the continuing knowledge of Greek and Latin among European and American scholars. The characters in his stories, even if they are professors of geology, are all able to read the Latin Necronomicon; one of them even displays his Classical biases by noting that the translation was in "awkward Low Latin." Despite its seeming connections to Greco-Roman antiquity, the Necronomicon is fundamentally non-Western, and this is exactly why it was able to serve as an effective source of horror and alienation in Lovecraft's works. ${ }^{92}$

Bal-Sagoth handles its Chthonic Chronicles in much the same way, including excerpts

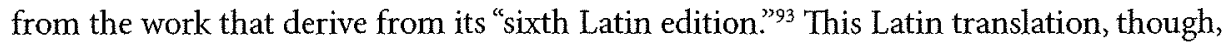
was evidently still interspersed with "glyphs, sigils, [and] occult pictograms" that revealed the text's Atlantean origins, and established its non-Western credentials. ${ }^{94}$ The Latin translation of the Chthonic Chronicles is accessible to the narrators of Bal-Sagoth's songs and associated stories, who tell the story of the band's larger fictional world in lyrics and accompanying liner notes. All these narrators are antiquarians active around the turn of the twentieth century, much like the characters in Lovecraft's stories. ${ }^{95}$ But these antiquarian narrators direct almost all their scholarly attention away from Greco-Roman antiquity, despite their evident familiarity with Latin. Instead, all the songs featuring these antiquarians are about other premodern sites and civilizations: Angkor Wat, Atlantis, Babylon, and Egypt, along with the Olmec, Mayans, and Aztecs.

In contrast, Greco-Roman antiquity has a muted presence in the Chthonic Chronicles, appearing in only one song. This is a short, lyric-less piece (it includes wordless vocals) called "To Storm the Cyclopean Gates of Byzantium" and is accompanied in the album's liner notes by a short story written from the perspective of a centurion serving in the army of the emperor Septimius Severus during the Siege of Byzantium (193-195 CE) ${ }^{96}$ Tellingly, this song has no connection to the antiquarian narrators who appear in all of the other songs and stories about the Chthonic Chronicles. It scarcely even qualifies as a conventional metal song; there are no guitars, drums, or bass, much less any screamed vocals, as there are in all the other songs on the album about the Chthonic Chronicles. These other songs and stories all emphasize the horrific and mysterious associations of non-Western civilizations, again following the example of Lovecraft. ${ }^{97}$ Evidently, Roberts was unable to imagine a song that explored the lurking evil and danger that might be encountered by an archaeologist in a Greek or Roman ruin, as he was easily able to do for the ruins of non-Western civilizations in several different songs. These make extensive use of the tritone, an interval called by music theorists the Diabolus in musica ("the Devil in music") that has traditionally been used to evoke feelings of danger and fear. ${ }^{98}$ Even when one of the antiquarian narrators displays his Classical training and swears an oath "by the erudite tongue of Herodotus", it immediately becomes clear that he is celebrating the discovery of "arcane secrets" about the non-Greek divinity Khthon in an "ancient Coptic papyrus. " Consciously or not, Bal-Sagoth follows the example of Lovecraft in turning away from Greco-Roman antiquity in its exploration of the premodern world. Just as Lovecraft found little potential for horror in Greco-Roman antiquity, likewise BalSagoth has deemed Greece and Rome an inappropriate source for exploration in its unique brand of metal.

The influence of Lovecraft and Howard has led Bal-Sagoth to engage little with GrecoRoman antiquity in its reception of premodernity, following the same pattern that appears in the albums of Celtic Frost, Therion, and other esoteric bands. Bal-Sagoth's albums contain none of the explicit references to the occult that are so obvious in the albums of Celtic Frost and Therion, but the band still shares their fascination with the most arcane and mysterious elements of the premodern world, rather than Greece and Rome. Bal-Sagoth nonetheless follows the example of Lovecraft and Howard in drawing inspiration from Greco-Roman antiquity in its exploration of the world's distant and forgotten past, again much as Celtic Frost and Therion employ Greek and Latin words and phrases in their albums. The pulp and occult influences working on these three bands have helped them to present an alternative vision of the premodern world that mostly bypasses Greece and Rome, even as they take for granted nineteenth and earlytwentieth century assumptions about these civilizations. Greco-Roman antiquity is still present in the albums of Bal-Sagoth, Celtic Frost, and Therion, but only alongside larger 
engagements with other periods and civilizations of the world's premodern past. In the end, the more familiar and famous aspects of Greece and Rome have little place in the music of the three bands, which instead look to authors like Howard, Lovecraft, and Crowley as sources of inspiration for their engagement with antiquity.

\section{Conclusion}

The three bands discussed in this chapter serve to establish that Classical reception in metal needs to be placed within the broader context of the genre's fascination with premodernity, and its interest in the occult tradition and pulp literature. Works of Greek and Latin literature have only a minor place in the receptions of Greco-Roman antiquity by Celtic Frost, Therion, Bal-Sagoth, and other esoteric bands. Esoteric bands are more likely, overall, to be captivated instead by a completely spurious piece of "ancient" literature. This is none other than Lovecraft's own Necronomicon, which a large number of people with interests in the occult believe is a real book, rather than an invented fiction. ${ }^{100}$ Support for this belief comes from the many versions of the book that have been published and presented as authentic, above all the "Simon" Necronomicon, which has been a fixture in the occult sections of bookstores since its first publication in the late $1970 \mathrm{~s} .{ }^{101}$ With prefatory material and an introduction authored by the mysterious Simon, this Necronomicon claims that there are major links between the fictional world depicted in Lovecraft's stories, the occult teachings of Crowley, and the magic and mythology of ancient Sumer. ${ }^{102}$ Though the book is presented as the work of Abdul Alhazred, Lovecraft's own "Mad Arab," Simon's preface claims that the manuscript he accessed was in Greek, rather than Arabic, recalling Lovecraft's suggestion that the Necronomicon was translated from Arabic to Greek in the tenth century. ${ }^{103}$ Simon's Necronomicon thus serves as a fitting symbol for the status that Greco-Roman antiquity has for many metal bands. Though the work has a Greek title and was ostensibly even translated from a Greek manuscript, Simon's Necronomicon brings together the major interests of esoteric metal bands in pulp literature, the occult tradition, and the most arcane aspects of the world's ancient history. Simon's Necronomicon, which has been quoted or alluded to in the lyrics of many death metal bands, is a strong contender for the title of the most popular and influential "ancient" book within metal. ${ }^{104}$ The major influence of this book provides a final reminder that esoteric metal bands display limited interests in Greece and Rome when they approach the ancient world. Alternative traditions about antiquity and alternative canons of ancient literature, real or imaginary, have instead been of greater significance within esoteric metal. ${ }^{105}$

\section{Notes}

1. Both appear in the notes accompanying the song "(Ode to ancient) Europa."

2. The Song of Roland is the inspiration for the song "... And the Horns Called for War." The twelfth-century account of Lindisfarne is Symeon of Durham's Book on the Origin and
Progress of this the Church of Durham (see Rollason 2000 for Latin text and translation). Symeon's account serves as inspiration for the song "Lindisfarne (Anno 793)."

3. Bierce's story was called "An Inhabitant of Carcosa." It has been republished many times, including in a collection by Thin (2002:55-60). For the later history of Carcosa, including its appearance in True Detective, see Tybjerg (2016: 110-12).

4. Theys' claim is confused. There is no reference to Carcosa in The Satanic Bible (LaVey 1969). There is, however, a reference to Carcosa in a companion volume to this work, The Satanic Rituals (LaVey 1972: 54).

5. These comments all come in Theys' liner notes accompanying the lyrics to the song "Dim Carcosa." For the history of Carcaso and its status in the Roman Empire, see Bekker-Nielsen (2008: 248-50).

6. For characteristics of these subgenres, see Introduction (this volume).

7. See Kahn-Harris (2007: 61).

8. For discussion, see Granholm (2011a: 518).

9. For the occult tradition, and its emphasis on rejected knowledge, see especially Hanegraaff (2012).

10. See Schein (2008: 79).

11. For the history of Weird Tales, see Haining (1990) and Hoppenstand (2013).

12. For discussion of the Classical tradition as it was conceived in the nineteenth and early twentieth centuries, see Budelmann and Haubold (2008: 13-14) and Schein (2008: 79).

13. For Orientalism in Weird Tales stories, see McGeough (2015: 373-86), and further discussion below. For the occult tradition, see Granholm (2011b:22-4). For more on the influence of Orientalism on metal, see Olabarria (this volume).

14. For the controversies surrounding Theys and his interests in Flemish history, see his comments in Geegor (2015). On nationalism in black metal, see Spracklen, Lucas, and Deeks (2014: 56-60).

15. See Olson (2011: 147-48)

16. For the apolitical status of Norwegian black metal in this period, see Olson (2011:138).

17. Note the growing interest in the study of magic, as observed by Collins (2008: xi). Consider also the increased attention on Greek and Roman astrology, including studies by Barton (1994) and Greenbaum (2016).

18. See Farley (2009: 78-80).

19. For the influence of Black Sabbath on later bands treating occult subjects, see Granholm (2011a: 517). For Crowley and his reception in popular music, see Lachman (2014: 322-46).

20. Spinal Tap, "Stonehenge," Spinal Tap (1984). The ellipses are in the original.

21. See Sharpe-Young (2007: 479-82) and Wagner (2010: 116-24). Note also that Celtic Frost's first three albums appear among the top 500 metal albums as voted by fans in a major worldwide poll (Popoff 2004: 90-3 and 102).

22. For overviews of the band's history and significance, see Ekeroth (2006: 411); Sharpe-Young (2007: 488-91) and Wagner (2010:233-38). Note that Therion's album Theli (1996), the band's first to feature extensive use of Classical instrumentation and choral vocals, appears among the top 200 albums of metal history, as voted by fans (Popoff 2004: 165-66).

23. See Trompf (2013: 375-403). Therion's Beloved Antichrist (2018), a three-CD-length rock opera, contains one track entitled "Hail Caesar!" 
24. See Hanegraaff (2012: 7-12).

25. Fischer (2000: 58).

26. Fischer (2000: 74), Fischer (2009: 133).

27. Fischer (2009: 138)

28. Note especially the songs "Babylon Fell (Jade Serpent)," from Into the Pandemonium (1987), and "A Descent to Babylon (Babylon Asleep)," from Parched with Thirst Am I and Dying (1992).

29. See Fischer (2009: 187).

30. For an overview of the tablets, including an edition with translation, see Graf and Johnston (2013).

31. See Edmonds (2011:3-14) and Graf and Johnston (2013:50-65) for a history of scholarship on the tablets.

32. Breslin (1977: 4, 6). Previous English translations of the tablets which might have been available to the band in 1992 rendered the key phrase differently. Note Guthrie (1952: 173) and Harrison (1908: 666), both of which translate the phrase as "I am parched with thirst and I perish."

33. Fischer (2000: 333 n. 90).

34. See Breslin (1977:6) and Graf and Johnston (2013:4-5).

35. Crowley (1913:35).

36. See "Eparistera Daimones" ("n.d.").

37. Fischer (2013) in a reply posted to DrMorbid (2013).

38. One fan notes that the word "chasma" is used in the field of astrogeology, while another speculates wildly that Melana might refer to the river Nile. See the replies to DrMorbid in DrMorbid (2013).

39. For the magical power attributed to ancient languages in contemporary culture, see Pitcher (2009: 29).

40. For the name-change, see Ekeroth (2006: 121).

41. For the influence of Celtic Frost on Therion, see Wagner (2010: 234).

42. See Granholm (2014: 60-1). My discussion of the order depends heavily on the studies of Granholm (2005) and (2014); the latter is an updated, but shorter, version of the former, and I shall cite from both.

43. Granholm (2012: 563). For more on Karlsson, see Granholm (2014: 70-2). Karlsson was not the lyricist for Therion's two most recent studio albums, though both differ in character from the band's previous releases. Les Fleurs Du Mal (2012) contains fifteen covers of French pop songs from the 1960s and 1970s. Beloved Antichrist (2018), meanwhile, is a massive rock opera, and something of a passion project for the band's founder.

44. Granholm (2014: 195).

45. For the use of the phrase in Dragon Rouge rituals, see Granholm (2014: 107).

46. Granholm (2014: 198; 76, 107-8).

47. See Granholm (2014: 107-8), with additional details on the order's lectures in Granholm (2005: 201-3).

48. See Granholm (2005: 197-98; the quotation is from $198 \mathrm{n.} 76$ ).

49. See also the discussion of Granholm (2012: 568-69).
50. See Ekeroth (2006: 194-95), Wagner (2010: 233-35), and especially "Interview with Christofer Johnsson" (2004), which includes an album-by-album overview of the band's early experimentation.

51. Note especially "In the Desert of Set," Theli (1996). For Egypt in metal, see Olabarria (this volume).

52. See Granholm (2012: 563). For more on Bureus, see Håkansson (2012: 500-22).

53. See Håkansson (2012: 505-7).

54. Therion, "Adulruna Rediviva," Gothic Kabbalah (2007).

55. See Ebeling (2007:62) for a similar succession in the works of the influential Renaissance scholar Marsilio Ficino, who translated both the works of Plato and the works attributed to Hermes Trismegistus into Latin.

56. See Ebeling (2007: 91-3).

57. On the music that has influenced Therion, see "Interview with Christofer Johnsson" (2004).

58. See Granholm (2013: 5-33)

59. For biographies of Lovecraft and Howard, see, respectively: Joshi (2013) and Finn (2013).

60. Metallica, "The Call of Ktulu," Ride the Lightning (1984). The band offered an alternative spelling of Cthulhu to make the word easier to pronounce, and to avoid the possibility of legal action for copyright infringement. See McIver (2009: 122). For a thorough review of Lovecraft-inspired songs in metal, see Hill (2006: 43-114) and Norman (2013: 193-208).

61. Hall (2007: 4-11) offers a discussion of Howard's sizable presence in metal. See also Sammon (2007) for the influence and reception of Conan in popular culture.

62. On the appeal of Lovecraft to metal, see Norman (2013: 203-4). On Howard's appeal, see Hall (2007: 7).

63. For an overview of the band's history and discography, see Sharpe-Young (2007: 478-79).

64. On Nile, see Hill (2006: 95) and Olabarria (this volume). On Mercyful Fate, see Hill (2006: 88-9).

65. For other bands with interests similar to Bal-Sagoth's, note, especially, the example of Ancient Rites (above), Manilla Road (see Sharpe-Young 2007: 310-11), and Absu (see Sharpe-Young 2007: 224-25).

66. See Roberts (2015) for his first published story in a collection written by metal musicians.

67. The story has not been included in the recent multi-volume edition of Howard's works published by Del Rey. It is, however, included in several older collections, such as Howard (1963: 91-128).

68. See the interview of Stefanis (2006) for the band's self-characterization.

69. See Messer (2006).

70. For the most extreme example in the band's discography, note "And Lo, When the Imperium Marches Against Gul-Kothoth, then Dark Sorceries Shall Enshroud the Citadel of the Obsidian Crown," Starfire Burning Upon The Ice-Veiled Throne Of Ultima Thule (1996). See Åshede and Foka (this volume) for Theatre of Tragedy's use of archaizing English.

71. See Roberts (1998). This is the only version of the glossary currently available to me online; it includes content only from the band's first four albums.

72. The band's most sustained engagement with Greco-Roman antiquity comes in a single song This is "Blood Slakes the Sand at the Circus Maximus," Battle Magic (1998). It concerns the experience of an Iceni gladiator in the aftermath of Boudicca's rebellion against Rome. See below for discussion of another song that engages briefly with Greco-Roman antiquity.

73. See Shanks (2013: 13-34). 
74. Note the titles of three albums for references to Atlantis, Lemuria, and Ultima Thule, respectively: Atlantis Ascendant (2001), A Black Moon Broods Over Lemuria (1995), and Starfire Burning Upon the Ice-Veiled Throne of Ultima Thule (1996). Hyperborea appears in three songs that all form part of the same sequence: "The Splendour of a Thousand Swords Gleaming beneath the Blazon of the Hyperborean Empire." Part I is on the band's 1996 album; Part 2 is on Battle Magic (1998); and Part III is on the band's 2001 album. Mu appears in "The Thirteen Cryptical Prophecies of Mu," from The Power Cosmic (1999).

75. For the influence of Plato's fictitious Atlantis, see Vidal-Naquet (2007). For Hyperborea, see Bridgman (2005) and, for Ultima Thule, see Mund-Dopchie (2009). See also Romm (1992) for discussion of the interests of Greek and Roman authors in places located at the edges of the world.

76. See de Camp (1970: 44-50) for Mu and (1970: 51-75) on Lemuria.

77. See Howard (2002: 381-98 and 423-25) for his famous essay "The Hyborian World," and for two of his own hand-drawn maps of this world, respectively. For the intended familiarity of his world, see Shanks (2013: 14).

78. For the band's map, see Roberts (2009a). One version of it is also included in the liner notes to The Chthonic Chronicles (2006).

79. Bal-Sagoth, "The Splendour of a Thousand Swords Gleaming beneath the Blazon of the Hyperborean Empire (Part III)," Atlantis Ascendant (2001). "Imperius" is not a word attested in Classical Latin, and it is used only as a noun in later Latin, where it means "emperor." See Souter (1949, s.v. "imperius").

80. "Draconis Albionensis," Atlantis Ascendant (2001). The song's title is evidently supposed to mean something like "English Dragon(s)." See OLD (1996), s.v. "albion."

81. The quotation is from Beowulf 3180: "Wyruld Cyninga" ("of the earthly kings"). I cite from the edition of Fulk, Bjork, and Niles (2008), which includes a glossary entry for the phrase at 460 .

82. See "The Haunter of the Dark" in Lovecraft (1999: 344) for citations of many of the books invented by Lovecraft and his circle, with the accompanying explanatory note on the passage by Joshi (2013: $418 \mathrm{n}$. 15).

83. On Lovecraft's Necronomicon, see Harms and Gonce (2003:3-28).

84. Lovecraft (1995: 52-3).

85. Lovecraft (1995: 52). As Lovecraft here notes, Al Azif refers to the "nocturnal sound" made by insects and is associated with the "howling of daemons."

86. All these peoples are mentioned in the album's liner notes for the song "The Sixth Adulation of his Chthonic Majesty", The Chthonic Chronicles (2006). There is a reference to "Old High Atlantean" in the notes for "Six Score and Ten Oblations to a Malefic Avatar," The Chthonic Chronicles (2006)

87. As a parallel, note the example, cited above, of Metallica spelling "Cthulhu" as "Ktulu" Compare also the common alternative spelling of "true cult" as "trve kvlt" within black metal, where the phrase is meant to signify authenticity. See Lucas, Deeks, and Spracklen (2011:286 and 289).

88. See Roberts (2009b).

89. Note the remarkable suggestion of Hill (2006: 56): "I believe the term 'Chthonic' means 'related to Cthulhu."'

90. See Lovecraft (1995: 53), who explains that the original Arabic version was lost in the eleventh century, and that the Greek translation may also be completely lost, despite some rumors of its continued survival.
91. See "The Festival" in Lovecraft (1999: 117). Note also "At the Mountains of Madness" in Lovecraft (2001:250) for the familiarity of a geology professor with the Latin translation of the Necronomicon.

92. On Lovecraft's reception of the ancient Near East in his stories, see McGeough (2015: 373-86).

93. See the liner notes to "The Sixth Adulation of his Chthonic Majesty," The Chthonic Chronicles (2006).

94. "Six Score and Ten Oblations to a Malefic Avatar," The Chthonic Chronicles (2006).

95. See Müller (2013: 57-8) for discussion of Lovecraft's antiquarian characters.

96. From The Chthonic Chronicles (2006). The story explains that Septimius Severus was eager to find a copy of the Chthonic Chronicles in the library of Byzantium. It is interesting to note that Severus did actively seek out copies of ancient magical books when he visited Egypt (Cass. Dio 75.13.2), though it is by no means clear that Roberts' use of the emperor in the story is anything more than coincidental.

97. See McGeough (2015: 377) for discussion of how the ancient Near East served in Lovecraft's stories as a "meaningful referent for danger, anarchy and mysticism."

98. Note, especially, the use of the tritone interval in the first twenty seconds of "The Dreamer in the Catacombs of Ur," Atlantis Ascendant (2006). For more on the tritone, see KahnHarris (2007: 31).

99. "Unfettering the Hoary Sentinels of Karnak" The Chthonic Chronicles (2006).

100. See Harms and Gonce (2003: xvi). Note also Steadman (2015) who offers a discussion of Lovecraft's reception by contemporary occult groups.

101. Simon (1977). See also the discussions of Harms and Gonce (2003: 39-48) and Steadman (2015: 93-116).

102. Simon (1977: xi-xiii) and the "Chart of Comparisons" between Lovecraft, Crowley, and Sumer on $(1977$ : $x$ xxxix $-\mathrm{xl})$.

103. Simon (1977: $x x x i)$.

104. See Hill $(2006: 66,73-4,95)$ for discussion, respectively, of songs by Morbid Angel, Vader, and Nile that quote or allude to the Simon Necronomicon.

105. I am grateful to Ralph Patrello, Matt Unangst, Sean Wempe, and the volume editors, Kris Fletcher and Osman Umurhan, for their comments on drafts of the paper at various stages of the project, and to Jason Gersh for providing valuable advice on matters relating to musicology. 